\title{
PELATIHAN TEKNIK MODELING UNTUK MEMBANGUN KOMUNIKASI INTERPERSONAL ORANG TUA DENGAN ANAK DI ERA DIGITAL PADA KPM PROGRAM KELUARGA HARAPAN KECAMATAN WONOSEGORO
}

\author{
Ahmad Jawandi, Eko Adi Putro \\ Program Studi Bimbingan dan Konseling \\ Fakultas Keguruan dan IImu pendidikan, Universitas Slamet Riyadi, \\ Jl. Sumpah Pemuda No.18 Surakarta, Jawa Tengah \\ ahmadjawandi@gmail.com
}

Masuk: Mei 2020

Revisi: Juni 2020

Diterima:Juli 2020

Terbit: Agustus 2020

Keywords:

Modeling Techniques, Interpersonal

Communication

\section{Kata kunci:}

Teknik Modeling,

Komunikasi Interpersonal

P-ISSN: 2598-2273

E-ISSN: $2598-2281$

\begin{abstract}
This digital diera greatly affects the communication of children and parents, someone who is far near and who feels distant because there is social media. Lots of communication mistakes made by parents towards children at home. Parents who can not talk with opponents will cause estrangement or conflict, on the contrary parents who can receive and communicate effectively will make children grow, develop, make changes developed, learn to correct problems, the more healthy, the more productive, creative and able to actualize the full potential. Therefore, parents need to develop appropriate attitudes and need communication skills to strengthen the relationship between parents and children.

Parents must get several ways to make effective communication, one of them through behavioral modeling techniques. The target service is the Family Hope Beneficiary (KPM) Family Program in the Wonosegoro District. The purpose of this community service activity is to provide a training method in making effective interpersonal communication between parents and digital diera children through technical modeling.

The method used in this community service is modeling to develop effective interpersonal communication in the family. In modeling this method using several special techniques namely Symbolic Model, Live Model and Rehearsal Behavior techniques. Implementation of community service is carried out with seminars and training through lectures, discussions and brain storming, questions and answers, and the practice of using directly. Modeling technique training was conducted as an effort to build effective interpersonal communication between parents and digital diera children conducted 4 meetings. The expected outcome of community service is the realization of parents' understanding of building effective interpersonal communication between parents and digital children who are applied in everyday life through technical modeling.
\end{abstract}


Diera digital ini sangat mempengaruhi komunikasi anak dan orang tua, seseorang yang jauh menjadi dekat dan yang dekat terasa jauh karena adanya media sosial. Banyak sekali kesalahan komunikasi yang dilakukan orang tua terhadap anak-anaknya di rumah. Orang tua yang kurang bisa berkomunikasi dengan anaknya akan menimbulkan kerenggangan atau konflik hubungan, sebaliknya orang tua yang dapat menerima dan berkomunikasi secara efektif sebagaimana adanya akan membuat anak cenderung dapat tumbuh, berkembang, membuat perubahan-perubahan yang membangun, belajar memecahkan masalah-masalah, secara psikologis semakin sehat, semakin produktif, kreatif dan mampu mengaktualisasikan potensi sepenuhnya. Karena itu, orang tua perlu menumbuhkan sikap yang tepat dan mempelajari keterampilan komunikasi yang efektif untuk menguatkan hubungan antara orang tua dan anak. Orang tua harus mengambil inisiatif dengan mengikuti beberapa cara untuk membangun komunikasi yang efektif, salah satunya melalui pendekatan behavior teknik modeling. Sasaran pengabdian adalah Keluarga Penerima Manfaat (KPM) Program Keluarga Harapan di Kecamatan Wonosegoro. Tujuan dalam kegiatan pengabdian masyarakat ini adalah memberikan metode pelatihan dalam membangun komunikasi interpersonal yang efektif antara orang tua dengan anak diera digital melalui teknik modeling.

Metode yang digunakan dalam pengabdian masyarakat ini adalah modeling sebagai pendekatan membangun komunikasi interpersonal yang efektif dalam keluarga. Dalam metode modeling ini menggunakan beberapa teknik khusus yaitu teknik Symbolic Model, Live Model dan Behavior Rehearsal.. Pelaksanaan pengabdian kepada masyarakat ini, dilaksanakan dengan seminar dan pelatihan melalui ceramah, diskusi dan ramu pendapat (brain storming), tanya jawab, serta praktik secara langsung. Pelaksanaan pelatihan teknik modeling sebagai upaya dalam membangun komunikasi interpersonal yang efektif orang tua dengan anak diera digital dilakukan sebanyak 4 kali pertemuan. Hasil yang diharapkan dari pengabdian masyarakat yang dilakukan adalah terwujud pemahaman orang tua tentang pentingnya membangun komunikasi interpersonal yang efektif antara orang tua dengan anak diera digital yang diaplikasikan dalam kehidupan sehari-hari melalui teknik modeling.

\section{PENDAHULUAN}

Komunikasi adalah hal yang paling mendasar dalam kehidupan setiap manusia. Manusia sebagai pribadi maupun makhluk sosial akan saling berkomunikasi dan saling mempengaruhi satu sama lain dalam hubungan yang beraneka ragam, dengan gaya dan cara yang berbeda pula. Komunikasi juga menunjukkan suasana aktif, diawali dari seorang komunikator menciptakan dan menyampaikan pesan, menerima umpan balik dari komunikan, dan begitu seterusnya pada hakikatnya 
menggambarkan suatu proses yang senantiasa berkesinambungan (Suranto 2010:195). Dalam suatu hubungan antar pribadi, peran komunikasi menjadi suatu sumber yang penting dalam kehidupan seseorang untuk mengidentifikasi pribadi dan untuk mengekspresikan siapa dirinya. Hal itu merupakan cara utama untuk membangun, memperbaiki, mempertahankan, dan mengubah hubungan baik dengan orang lain.

Komunikasi antara orangtua dengan anak dalam lingkup keluarga, termasuk dalam kelompok komunikasi interpersonal. Joseph de Vito (2009:18) mendefinisikan komunikasi interpersonal sebagai proses pengiriman dan penerimaan pesan di antara dua orang atau lebih secara formal maupun informal. Komunikasi interpersonal mengharuskan pelaku bertatap muka antara dua orang atau lebih dengan membawa pesan verbal maupun nonverbal sehingga masing-masing bisa memahami satu sama lain dan berinteraksi secara efektif. Setiap keluarga memiliki pedoman-pedoman mengenai aturan-aturan komunikasi yang dapat dipahami (Mulyana, 2005:216). Keluarga mempunyai komunikasi yang tertata melalui aturan pada budaya keluarga itu sendiri, yang dibangun oleh orangtua guna membentuk karakter anak dan teladan orangtua. Pada setiap keluarga, komunikasi dapat dibina dengan baik melalui pola komunikasi yang terdapat pada praktik sehari-hari yang biasa dilakukan keluarga tersebut, sehingga apa yang didapat pada cara berkomunikasi sehari-hari dalam kehidupan berkeluarga dapat diimplementasikan dalam kehidupan bermasyarakat.

Relasi antara orang tua dan anak dalam keluarga adalah relasi yang dibangun di atas dasar komunikasi. Bahkan, setiap saat kita berkomunikasi dengan anggota keluarga yang lain. Kita berkomunikasi pada saat makan, berkomunikasi pada saat menonton televisi, berkomunikasi pada saat berbelanja di mall, bahkan berkomunikasi untuk menentukan tempat berwisata, dan lain sebagainya. Namun, satu hal yang perlu disadari bahwa sebuah komunikasi efektif tidak saja diukur dari keseringan komunikasi itu dilakukan tetapi juga diukur dari kualitas komunikasi.

Diera digital ini sangat mempengaruhi komunikasi anak dan orang tua, seseorang yang jauh menjadi dekat dan yang dekat terasa jauh karena adanya media sosial. Dalam satu ruangan yang sama seringkali orangtua maupun anak lebih senang bermain dengan gadget ataupun HP dari pada untuk bercengkerama dan 
berbincang bersama keluarga. Banyak sekali kesalahan komunikasi yang dilakukan orang tua terhadap anak-anaknya di rumah. Kesalahan komunikasi itu antara lain: ada kecenderungan memerintah; mengabaikan anak; mengancam anak; menceramahi/menggurui; menginterogasi; memberi label tertentu (malas, nakal, bandel, lelet, dan lain-lain); membanding-bandingkan; menghakimi; menyalahkan; menyindir; dan membohongi. Pola komunikasi seperti ini akan membuat anak menjadi tidak percaya diri; merasa tidak dihargai yang berakibat pada dia sendiri tidak menghargai dirinya; merasa disepelehkan; selalu merasa takut/tidak dilindungi; merasa dijauhkan dari perhatian; dan pada akhirnya anak tidak mampu mengaktualisasikan dirinya ditengah kehidupan sosial bersama teman-temannya.

Pola komunikasi seperti ini disadari atau tidak disadari sering dilakukan orangtua ketika menghadapi anak-anak bermasalah dalam lingkungan sosial mereka. Seharusnya model komunikasi yang dibangun adalah komunikasi yang menumbuhkan rasa percaya diri sehingga kreativitas dan potensi diri anak dapat diaktualkan secara maksimal dalam dunia bermain bersama teman-temannya di lingkungan masyarakat maupun di lingkungan sekolahnya. Orang tua hendaknya menjadi teman curhat yang menampung segala keluh kesah anak dan menjadi sumber solusi dari berbagai permasalahan yang dihadapi anak.

Orang tua yang kurang bisa berkomunikasi dengan anaknya akan menimbulkan kerenggangan atau konflik hubungan, sebaliknya orang tua yang dapat menerima anaknya sebagaimana adanya akan membuat anak cenderung dapat tumbuh, berkembang, membuat perubahan-perubahan yang membangun, belajar memecahkan masalah-masalah, secara psikologis semakin sehat, semakin produktif, kreatif dan mampu mengaktualisasikan potensi sepenuhnya.

Kendala serupa juga dialami oleh Mitra yang banyak mengalami permasalahan komunikasi antara orang tua dan anak. Berdasarkan wawancara yang dilakukan kepada beberapa orang tua anggota mitra pada tanggal 18 januari 2019, diperoleh beberapa informasi bahwa banyak orang tua yang mengeluhkan terkait perilaku anaknya yang kurang baik dan mengarah pada kenakalan; anak tidak mau mendengarkan perkataan orang tua; anak kurang mengerti keinginan orang tua; sering terjadi konflik terkait perbedaan pendapat; beberapa ibu-ibu mengakui terlalu disibukkan dengan pekerjaan dan bermain media sosial di group, sehingga kurang 
memperhatikan kebutuhan anak; serta jarang berbicara secara mendalam dari hati ke hati terkait permasalahan yang dihadapi putra-putrinya. Sedangkan wawancara yang dilakukan kepada beberapa anak dari anggota Mitra menyampaikan bahwa orang tua terlalu mengekang, anak sering dimarahi dan menjadi sasaran emosional orang tua, kurang mengerti kebutuhan dan keinginan anak, orang tua kurang bisa menjadi tempat curhat bagi permasalahan yang dihapi anak, kurang percaya dan kecenderungan menyalahkan anak. Sebagian besar orang tua anggota PKH memiliki pendidikan yang kurang, sehingga membutuhkan bimbingan dan informasi tentang pola asuh orang tua yang tepat.

Jika keadaan yang disebabkan miscommunication seperti ini terus berlanjut maka bisa saja hubungan antara orang tua dan anak semakin buruk. Karena itu, orang tua perlu menumbuhkan sikap yang tepat dan mempelajari keterampilan komunikasi yang efektif untuk menguatkan hubungan antara orang tua dan anak. Orang tua harus mengambil inisiatif dengan mengikuti beberapa cara untuk membangun komunikasi yang efektif, salah satunya melalui pendekatan behavior teknik modeling.

Teknik modeling merupakan teknik konseling dalam pendekatan behavioral yang berakar dari teori Albert Bandura dalam teori belajar sosial, yaitu teknik untuk merubah, menambah maupun mengurangi tingkah laku individu dengan belajar melalui observasi langsung (observational learning) untuk meniru perilaku orang maupun tokoh yang ditiru (model) sehingga individu memperoleh tingkah laku baru yang diinginkan (Shaleh, 2004). Sedangkan Alwisol (2014: 292) menjelaskan bahwa teknik modeling merupakan teknik yang menekankan pada pelibatan penambahan atau pengurangan tingkah laku yang teramati, menggeneralisir berbagai pengamatan sekaligus, melibatkan proses kognitif, bukan sekedar menirukan atau mengulangi apa yang dilakukan oleh seorang model. Hal ini diperkuat oleh Bandura (dalam Nelson, 2012), menyatakan bahwa salah satu cara utama dimana orang belajar adalah dari observational learning atau belajar dari model/panutan.

Tujuan penggunaan teknik modeling adalah agar mitra memperoleh tingkah laku sosial yang lebih adaptif, agar mitra bisa belajar sendiri menunjukkan perbuatan yang dikehendaki tanpa harus belajar lewat trial and error, membantu untuk merespon hal- hal yang baru khususnya kiat-kiat berkomunikasi yang efektif, 
melaksanakan scara tekun respon- respon yang diperoleh melalui pengamatan dari model, dan mengurangi respon- respon yang tidak layak. Teknik modeling ini relevan untuk diterapkan pada konseli yang mengalami gangguan-gangguan dalam komunikasi yang efektif.

Bertitik tolak dari fenomena di atas maka keluarga atau orang tua perlu perlu menumbuhkan sikap yang tepat dan mempelajari keterampilan komunikasi interpersonal yang efektif dengan anaknya. Sehingga penulis akan melakukan pelatihan teknik modeling untuk membangun komunikasi interpersonal orang tua dengan anak di era digital pada KPM Program Keluarga Harapan Kecamatan Wonosegoro.

\section{METODE PELAKSANAAN}

Metode yang digunakan dalam pengabdian masyarakat ini adalah teknik modeling sebagai pendekatan dalam membangun komunikasi interpersonal dalam keluarga di era digital. Dalam metode modeling ini menggunakan beberapa teknik khusus yaitu teknik Symbolic Model, Live Model dan Behavior Rehearsal. Symbolic Model merupakan modeling yang berbentuk simbolik biasanya didapat dari model film atau televisi yang menyajikan contoh tingkah laku yang dapat mempengaruhi pengamatnya. Live Model yaitu model hidup yang diperoleh dari konselor atau orang lain dalam bentuk tingkah laku yang sesuai, pengaruh sikap, dan nilai-nilai keahlian dalam menjalin komunikasi efektif dalam keluarga. Behavior Rehearsal, yaitu latihan tingkah laku dalam bentuk gladi dengan cara melakukan atau menampilkan perilaku yang mirip dengan keadaan sebenarnya.

Terdapat 4 tahapan strategi modeling yaitu rasional strategi, tahap modelling, partisipasi terbimbing, dan pengalaman sukses atau penguatan (Nursalim, 2014). Pelaksanaan pengabdian kepada masyarakat ini, dilaksanakan dengan seminar dan pelatihan melalui ceramah, diskusi dan ramu pendapat (brain storming), tanya jawab, serta praktik pendekatan behavior. Kriteria keberhasilan,dilihat dari banyaknya peserta dan antusias mereka dalam mengajukan pertanyaan dan tanggapan serta praktik "Teknik Modeling". Indikator pencapaian tujuan, dilihat dari penguasaan peserta terhadap materi yang disampaikan terwujud dengan pernyataan senang dan 
puas sesudah mendapatkan materi. Peserta menyatakan akan melaksanakan kitakiat bagaimana meningkatkan peran keluarga dalam membangun komunikasi interpersonal yang efektif.

\section{PEMBAHASAN}

Pelaksanaan pelatihan metode modeling sebagai upaya dalam membangun komunikasi interpersonal antara orang tua dan anak diera digital dilakukan sebanyak 4 kali pertemuan. Adapun pelaksanaannya dalam setiap pertemuan dapat dijelaskan sebagai berikut :

\section{Pertemuan pertama}

Pertemuan pertama dilaksanakan di rumah Ibu Sumirah pada tanggal 22 April 2019 yang dimulai pukul 10.30. Dalam pemberian treatment dibagi menjadi tiga tahap yang dapat dijabarkan sebagai berikut:

(a) Persiapan

Pertemuan diawali dengan salam pembuka, perkenalan dan presensi peserta. Selanjutnya mengkondisikan peserta dalam situasi yang menyenangkan (pembentukan good rapport). Pada saat pertemuan beberapa anggota kelompok terlihat tegang, gugup, kaku dan agak malu. Selanjutnya narasumber menjelaskan maksud dan tujuan pelatihan metode modeling sebagai upaya dalam membangun komunikasi interpersonal antara orang tua dan anak diera digital. Setelah anggota kelompok merasa nyaman, peneliti melanjutkan kegiatan dengan berdoa bersama.

(b) Pelaksanaan Kegiatan

Pada pertemuan pertama, narasumber memberikan materi tentang pentingnya menjaga komunikasi orang tua dan anak. Dilanjutkan dengan diskusi Tanya jawab terkait materi yang disampaikan. Tujuannya untuk menumbuhkan kesadaran orang tua tentang pentingnya menciptakan lingkungan keluarga yang kondusif untuk perkembangan anak khususnya dalam membangun komunikasi.

(c) Penutup 
Masuk pada tahap pengakhiran anggota kelompok menyampaikan apa saja yang diperoleh dari proses kegiatan. Narasumber membuat simpulan akhir sebagai penguatan supaya anggota kelompok dapat mengerti dan paham tentang materi yang dibahas. Evaluasi dalam kegiatan ini berupa kesan dan pesan dari peserta yang merasa puas dan senang bisa mendapat pengetahuan dari kegiatan pelatihan.

\section{Pertemuan Kedua}

Pertemuan kedua dilaksanakan di rumah Ibu Tukinah pada tanggal 25 April 2019 yang dimulai pukul 12.00. Dalam pemberian treatment dibagi menjadi tiga tahap yang dapat dijabarkan sebagai berikut:

(a) Persiapan

Pertemuan diawali dengan salam pembuka dan presensi peserta. Selanjutnya mengkondisikan peserta dalam situasi yang menyenangkan (pembentukan good rapport). Selanjutnya narasumber menjelaskan maksud dan tujuan kegiatan. Setelah anggota kelompok merasa nyaman, peneliti melanjutkan kegiatan dengan berdoa bersama.

(b) Pelaksanaan Kegiatan

Pertemuan kedua narasumber menampilkan modeling simbolik melalui video motivasi yang terkait komunikasi efektif orang tua anak, peserta melihat video, kemudian dilakukan FGD mengenai tanggapan mereka terkait video yang ditampilkan. Hasil diskusi disimpulkan dan disampaikan oleh pemateri sebagai evaluasi proses dan hasil kegiatan..

(c) Penutup

Pada tahap pengakhiran anggota kelompok menyampaikan apa saja yang diperoleh dari proses kegiatan. Narasumber membuat simpulan akhir sebagai penguatan supaya anggota kelompok dapat mengerti dan paham tentang materi yang dibahas. Evaluasi dalam kegiatan ini berupa kesan dan pesan dari peserta yang merasa puas dan senang

\section{Pertemuan Ketiga}


Pertemuan ketiga dilaksanakan di rumah lbu Tukinah pada tanggal 29 April 2019 yang dimulai pukul 13.00. Dalam pemberian treatment dibagi menjadi tiga tahap yang dapat dijabarkan sebagai berikut:

(a) Persiapan

Pertemuan dibuka dengan ice breaking, presensi dan pengkondisian peserta dalam situasi yang menyenangkan. Narasumber dengan sikap terbuka dan hangat menyambut kehadiran anggota kelompok, kemudian mengucapkan salam serta memimpin berdoa sebelum melakukan kegiatan berikutnya.

(b) Pelaksanaan Kegiatan

Mengundang life modeling, yaitu seorang yang dianggap pakar dalam menjalin hubungan orang tua anak. Life model menyampaian pengalamannya terkait pola asuh orang tua dan kiat-kiat cara berkomunikasi yang baik dengan anak. Kemudian dilanjutkan dengan tanya jawab dari peserta. Kedua orang yang diundang sebagai model adalah Bu Ari Ibu Lurah Wonosegoro sebagai wakil dari masyarakat yang dipandang mampu menciptakan interaksi positif dalam keluarga dan Pak Eko Dosen BK Unisri yang memiliki kepakaran dalam bidang konseling keluarga.

(c) Penutup

Pada tahap pengakhiran anggota kelompok menyampaikan apa saja yang diperoleh dari proses kegiatan. Narasumber membuat simpulan akhir sebagai penguatan supaya anggota kelompok dapat mengerti dan paham tentang materi yang dibahas. Evaluasi dalam kegiatan ini berupa kesan dan pesan dari peserta yang merasa puas dan senang

\section{Pertemuan Keempat}

Pertemuan keempat dilaksanakan di Rumah Ibu Nunuk pada tanggal 3 Mei 2019 yang dimulai pukul 10.00. Dalam pemberian treatment dibagi menjadi tiga tahap yang dapat dijabarkan sebagai berikut:

(a) Persiapan

Pertemuan dibuka dengan ice breaking, presensi dan pengkondisian peserta dalam situasi yang menyenangkan. Narasumber dengan sikap terbuka dan hangat 
menyambut kehadiran anggota kelompok, kemudian mengucapkan salam serta memimpin berdoa sebelum melakukan kegiatan berikutnya.

(b) Pelaksanaan Kegiatan

Pertemuan keempat menampilkan Behavior Rehearsal, yaitu latihan tingkah laku dalam bentuk gladi dengan cara melakukan atau menampilkan perilaku yang mirip dengan keadaan sebenarnya. Peserta diminta untuk melakukan simulasi bagaimana berkomunikasi yang baik dengan anak-anaknya. Kemudian dilanjutkan dengan pesan kesan dari beberapa peserta sebagai evaluasi akhir.

(c) Penutup

Pada tahap pengakhiran anggota kelompok menyampaikan apa saja yang diperoleh dari proses kegiatan. Narasumber membuat simpulan akhir sebagai penguatan supaya anggota kelompok dapat mengerti dan paham tentang materi yang dibahas. Evaluasi dalam kegiatan ini berupa kesan dan pesan dari peserta yang merasa puas dan senang

Pada setiap pertemuan narasumber selalu melakukan evaluasi proses dan hasil. Evaluasi proses dilakukan dengan bertanya secara langsung tentang kesan, pesan, dan apa yang diperoleh selama proses pelaksanaan kegiatan. Sedangkan evaluasi hasil dilihat melalui observasi langsung terkait pemahaman masyarakat yang ditunjukkan dengan perubahan sikap dan perilaku. Dari perubahan tersebut dapat disimpulkan bahwa metode modeling dapat membangun komunikasi interpersonal antara orang tua dan anak diera digital..

\section{CONCLUSION}

Berdasarkan pelaksanaan program pengabdian kepada masyarakat dapat disimpulkan bahwa metode modeling secara efektif mampu membangun komunikasi interpersonal antara orang tua dan anak diera digital. Hal ini dibuktikan dengan penguasaan peserta terhadap materi yang disampaikan terwujud dengan pernyataan senang dan puas sesudah mendapatkan materi. Peserta berjanji akan melaksanakan kita-kiat bagaimana membangun komunikasi interpersonal yang efektif antara orang tua dan anak diera digital. Keberhasilan juga dilihat dari banyaknya peserta dan 
antusias mereka dalam mengajukan pertanyaan dan data hasil observasi yang menunjukkan adanya perubahan sikap dan perilaku yang lebih positif.

\section{SARAN}

Berdasarkan simpulan yang sesuai dengan hasil penelitian, maka dapat diajukan beberapa saran kepada masing-masing pihak sebagai berikut:

1. Bagi Universitas:

a. Universitas hendaknya menyediakan akomodasi yang memadai untuk kelancaran pelaksanaan kegiatan pengabdian kepada masyarakat serta menjalin kerjasama dengan berbagai pihak dalam membangun masyarakat yang lebih baik.

2. Bagi Mitra:

a. Orang tua hendanya memahami berbagai kebutuhan perkembangan anak, khususnya peran orang tua dalam membangun komunikasi interpersonal yang efektif antara orang tua dan anak diera digital.

b. Pendekatan Behavior teknik modeling hendaknya dilakukan orang tua dalam lingkungan keluarga untuk membentuk komunikasi interpersonal yang efektif..

\section{DAFTAR PUSTAKA}

Alwisol. 2014. Psikologi Kepribadian. Malang: UMM Press

Aw, Suranto, 2010. Komunikasi Sosial Budaya. Yogyakarta. Graha Ilmu.

Corey. G. (2013). Teori dan Praktek Konseling dan Psikoterapi. Bandung : Refika Aditama.

De Vito, Joseph. 2009. Komunikasi Antarmanusia. Jakarta: Profesional Books

Erford, B. T. 2015. 40 Techniques Every Counselor Should Know (2nd eds). New Jersey: Pearson Education, Inc

Farozin \& Kartika N F. 2004. Pemahaman Tingkah Laku. Yogyakarta : Rineka Cipta 
Garry Martin \& Joseph Pear. 2015. Modifikasi Perilakau (makna dan penerapannya). Yogyakarta : Pustaka Pelajar

Gibson dan Mitchell. 2011. Bimbingan dan Konseling. Yogyakarta : Pustaka Pelajar

Mulyana, Deddy, 2005. IImu Komunikasi: Suatu Pengantar. Bandung. Remaja Rosdakarya.

Nelson, Richard-Jones. 2012. Pengantar Keterampilan Konseling. Yogyakarta: Pustaka Pelajar

Nursalim, Mochammad. 2014. Strategi dan Intervensi Konseling. Jakarta: Akademia Permata

Samuel T. Glading. 2012. Konseling: Profesi yang Menyeluruh. Jakarta : Indeks

Shaleh, A. R. (2004). Psikologi Suatu Pengantar dalam Prespektif Islam. Jakarta: Kencana. 